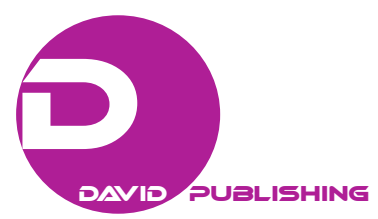

\title{
A New Strategy for Teacher Education in Hungary
}

\author{
Emese K. Nagy \\ Eszterházy Károly University, Eger, Hungary
}

\begin{abstract}
The goal of the education system is to educate adults who are physically, mentally, and spiritually healthy, are competitive in the labour market and thrive in society. According to a 2007 study by the Global Management Consulting Firm McKinsey, the effectiveness of the education system, i.e., the successful achievement of the above goals, depends on three factors: (a) the talent of teachers, i.e., the ability of the education system to attract the most dedicated and competent young people to the teaching profession; (b) the methodological preparedness of teachers; and (c) whether the education system is able to reduce the disadvantages resulting from the economic and social disparities of families. Of the above three conditions, which are the most important task of the Hungarian government's education policy to provide, the first two are related to teacher education and training, which makes the Hungarian teacher education system a key strategic area. The aim of the paper is to present the circumstances that create a need to reform the Hungarian teacher education and training, which are the European good examples that help to transform it. In the paper, we summarize our proposals that may or have helped to implement the reform of Hungarian teacher education.
\end{abstract}

Keywords: teacher education, training, reform, strategy

\section{The Goal of the Hungarian Government is to Increase the Effectiveness of Teacher Education}

In order to increase the effectiveness of teacher education, the Hungarian government considers it important that the most talented and dedicated young people enter into teacher education. The means to achieve this is to promote the teaching profession and teacher education and training. International experience shows that the teaching profession is one of the most recognized professions in countries with an effective education system. As a result, teacher education institutions face multiple oversubscriptions, from which they are able to select the most suitable young people with aptitude tests. In Finland, for example, an average of $20 \%$ of applicants are admitted to the teacher education programs for primary and secondary schools, while only $3 \%-5 \%$ of applicants are admitted to the education program for junior primary school teachers (Szabó \& Kärkkäinen, 2018).

In Hungary, triple counter-selection is implemented in teacher education (Varga, 2012):

1. Due to the small number of teacher education applicants, institutions set a low score (in many cases, the minimum required by law for higher education institutions) for certain subjects. Applicants could also be admitted to some undergraduate programs in sciences (e.g., chemistry, biology, and physics) with poor secondary school final examination results. As a result, not the best performing students were admitted into training.

2. Due to the lower teacher's salary compared to the average graduate salary after graduation it was primarily those who could not find a job in the competitive sector that found employment as teachers. In other

Emese K. Nagy, Ph.D., associate professor, Dean of Faculty of Pedagogy, Eszterházy Károly University. 
words, of the teacher education graduates, it was young people with less competitive knowledge that entered the teaching profession.

3. In the end, it was those who actually chose to go into teaching despite low salaries, often due to lack of opportunities as well that remained in the field. Excellent teachers who continued to work as a teacher, because of their commitment to the teaching profession even under these conditions played an extremely important role in the effectiveness of the education system.

After the 2010 change of government in the country, the education policy recognized the above challenges, to which it responded in the first step with a dramatic increase in teachers' salaries, averaging $50 \%$ between 2013 and 2017. As a result, the number of applicants whose first choice was teacher education increased by almost 60\% between 2013 and 2016.

Based on the above processes, it can be stated that positive changes occurred among the applicants for teacher education in the last decade. However, further progress needs to be made in order to achieve the goal formulated above. Based on the population data of the Education Office and the Central Statistical Office, the actual demand for teachers by subjects and regions can be predicted in the medium and long term, which can greatly contribute to determining the required number of students entering teacher education. However, this requires the government and higher education institutions to focus strongly on promoting the teaching profession, so that it can become the most recognized and attractive profession in Hungary as well. This is the only way to ensure that the most talented young people apply to teacher education programs.

Thus, it has become topical to rethink the current situation of teacher education and shape its vision. The teacher education of countries that are successful in this field and have remarkable strengths in some respects provides us with guidelines for this. In order to implement the national reform, we tried to find the segments that can be called for help, offer guidance, and can be followed in terms of reshaping the Hungarian teacher education.

\section{European Practices Contributing to Creating the Concept of Reforming the Hungarian Teacher Education}

In creating the Hungarian reform concept, we can rely on the public education and teacher education systems of countries that are at the forefront of and above the average of international knowledge measurements, such as Austria, England, Finland, the Netherlands, and Germany. A common feature of these countries is that they managed to stop teachers from switching to other careers and put their teacher education system at the service of increasing student achievement. They identified the shortcomings of teacher education and established its scientific basis, which is identical in several respects. Each country has a strength that can be exemplary for Hungary. There are places where salary settlement has remedied the problem, at other places the theoretical and practical training were combined in a professional manner and there are places where the possibility of career building is an example to follow.

\section{The Popularity of the Teaching Profession}

It is characteristic of well-functioning teacher education institutions that a sufficient number of students apply for admission there, which gives them the opportunity to select from a highly talented group of applicants. This is especially true in Finland, where the most successful applicants of a specific age cohort are admitted to teacher education programs. In Finland, due to multiple oversubscriptions, tests and interviews play an important role in screening and quality assurance. Ten percent of all applicants to the education science subjects were 
admitted to subjects in education science, which is only 3\%-5\% in terms of class teacher education (Szabó \& Kärkkäinen, 2018).

\section{Striving to Screen Students' Aptitude for the Teaching Profession}

In Germany, the selection of those eligible for the profession is based on the assumption that there are characteristics that are long-term, stable, durable, and measurable. Abilities are inferred on the basis of school or extracurricular performance (the average scores on the secondary school leaving examination, the subject marks in the secondary school leaving certificate) (Retrieved from http://www. Kmk.org...). As in the Netherlands students with not the most successful secondary school leaving exam results were previously admitted to teacher education institutions. Since 2010, after the first year, all students' language and mathematical knowledge has been assessed with a skills test, as a result of which the knowledge level of primary school teacher graduates has shown measurable improvement (Dutch Inspectorate of Education, 2015).

\section{Striving to Promote Applications for the Teaching Profession}

In England, applicants are motivated to choose the teaching profession through special scholarships and student loans to recruit more teacher candidates to shortage subjects. Accordingly, they increase support for teacher candidates in mathematics, physics, chemistry, and modern languages while reducing benefits for underperforming students. In London and Hastings, the "Now Teach" program was introduced in 2016 designed specifically for experienced professionals intending to change careers who are interested in teaching (Department for Education, 2018; Graduate Prospects Ltd. GB, 2018; Király, 2018; Universities \& Colleges Admissions Service [UCAS], 2018). Several measures were taken to make the teaching profession more attractive, new entry routes were opened and (especially since the introduction of tuition fees) the number of scholarships and the role of student loans provided at favourable conditions increased significantly. Today, there are no severe teacher shortages in England according to the Organisation for Economic Co-operation and Development (OECD) 2017 report (Department for Education, 2017) (about 1\% of teaching posts are not filled), except for general shortage subjects in Europe.

In Finland, there is a special admission process (erillishaku) for those who want to have their undergraduate degree recognised for credit when applying for a master's degree program or their pedagogical studies acquired previously, i.e., their courses completed at another university or open university (avoin yliopisto). In the Netherlands, higher education scholarships were replaced by student loans in 2015. The state provides low-interest loans to students to finance their studies (European Commission, 2017).

In Germany, the shortage of teachers in mathematics, information technology, technics and technology, and science is the most severe. In the case of teacher shortage, they do not insist on a pedagogy degree, for example, they may accept a disciplinary Master of the Arts degree in at least one subject and a Bachelor of the Arts degree in the other. Then the complex teacher training takes place during the traineeship (Retrieved from http://www. Kmk.org...).

\section{Recruiting Candidates Into the Teaching Profession}

In Germany, in addition to their own website, universities have a national teacher education portal for those interested in teacher education, students involved in teacher education, career starters and experienced teachers (Retrieved from http://www.bildungsserver.de). In the Netherlands, regular research is conducted and reports are made on the employment of newly qualified teachers and their retention in the teaching profession, which can facilitate application and planning (Major, 2018). 


\section{Striving to Settle Teacher Salaries}

In Austria, the New Legislation on the Employment of Teachers of 2013 (Dienstrechts-Novelle, 2013, Pädagogischer Dienst) introduces two important innovations: On the one hand, it modifies the salary scale by raising teachers' starting salaries (making the teaching profession more attractive), and creates new specialist functions (Fachkarrieren) in addition to the school principal and administrator roles (OECD, 2017). According to the parliamentary decision, teacher salaries will be settled from 2019 (Simić, Bachmann, \& Stančić, 2013).

In England, issues, such as the character, status, and state supervision of the teaching profession, the issue of input and output requirements for teacher education, supply, and demand issues, teachers' pay, and the issue of differentiated requirements for teachers at different levels of teaching come to the fore. Professional discussions on these issues led to the introduction of Teacher Standards, the elaboration and revision of teachers' salary scales (teacher life career model), the development of a traineeship system, the introduction of a new system of professional supervision and the transformation of in-service teacher training (Robinson, 2006). The prestige of the teaching profession in England is considered to be good in Europe according to the OECD report and the teaching profession is considered to be fundamentally attractive (OECD, 2017). The attractiveness of a profession is measured by many different factors, one of the most important being salaries levels. The salary earned by hour in England is above the European Union (EU) average (almost six times higher than in Hungary) and it can be said to be fairly stable in real term, despite the fact that teachers earn less than the national average of those both with a tertiary qualification and a similar level one, $80-90 \%$ of that (OECD, 2017).

In Finland, the teaching profession is extremely attractive, mainly because it is considered to be intellectual work that can be done autonomously, creatively, in a self-fulfilling and a socially useful way. Teacher work is not remarkably well paid in Finnish relations although teachers receive slightly more than the OECD average minimum salary (Szabó \& Kärkkäinen, 2018).

In the Netherlands, since 1993 Education Policy has considered increasing the status of the teaching profession and reducing the professional isolation of teachers as priority areas (Major, 2018). One element of this is to increase the teaching profession's attractiveness by raising teacher salaries. The ministry action plan raises the idea of performance-based extra pay (Teaching, 2020; 2011). Teacher salaries in the Netherlands are higher than the EU average. Nevertheless, mainly due to teacher shortages, raising beginning teacher salaries often arises as a factor of attraction for the teaching profession. Within the in-service training system, it is possible to increase the salary every six years, but this is not obligatory and it is also decided by the school at the local level.

In Germany, the popularity of the teaching profession is closely related to its social esteem and prestige, one of the supporters of which is the stable real value of salaries. The career is also attractive because-for at least some of the teachers who are civil servants - it means a career that is not threatened with the possibility of unemployment, predictable and a life career that makes it also possible to pursuea career (Halász, Santiago, Ekholm, Matthews, \& Mackenzie, 2004, as cited in Bikics, 2018).

\section{Striving to Create a Unified Teacher Education}

In Europe, Austria and Finland are working hard to create a unified teacher education. In Austria, according to the 2013 proposal of the National Council, teacher training became unified and is implemented in cooperation between universities and teacher training colleges (Szabó \& Kärkkäinen, 2018; Pesti, 2018). The aim of the master's degree programs is to deepen certain areas of undergraduate education and to broaden the range of students that can be taught. In Finland, professional teacher education is unified, with a degree that 
qualifies the holder to teach Grades 7-12 with one major and one minor in the base case. By completing a multidisciplinary module that prepares them for teaching their knowledge area in primary education, specialist teachers can also work as class teachers in the junior section. Dual entitlement (Kaksoiskelpoisuus) works in two directions. Otherwise, teacher and junior school teacher jobs require a master's degree (Retrieved from http://www.sool.fi...).

\section{Striving to Harmonize Initial and In-Service Teacher Education}

Regarding the harmonization of initial and in-service teacher education, in Austria at least one additional in-service teacher education program appears as mandatory in the programs offered by teacher education colleges in addition to primary and/or secondary teacher education programs (Pesti, 2018).

\section{Striving to Ensure the Unity and Interdependence of Practice and Theory}

In England, school-based education (often implemented in collaboration with universities) came to the fore over the last 35 years (Király, 2018). Teacher education is increasingly shifting towards teacher-cantered education, and the theoretical preparation of teachers is becoming shorter and has less pedagogical content. Since 2012 so-called "teaching schools" have become increasingly important in teacher education offering school-based teacher education programs, mostly forming a network of accredited teacher education providers. It offers practical training and takes place with support from experienced mentor teachers in the given school or in one of the schools in the network, in a regulated, contractual cooperation with a higher education institution. (Gov.UK, 2010)

In the Netherlands, teacher training and education is designed according to the right mix of theory and practice, financial support, and the needs of prospective teachers. According to the 2014 core curriculum, education is organized according to the principles of phenomenon-based and multidisciplinary education, which is also followed by teacher education. Their goal is to attract more students to the teaching profession and prevent early school leaving by the parallel emergence of the practical and theoretical elements of teacher education (Major, 2018). More and more institutions are creating a program, which is, on the one hand, due to changes in teacher education programs, and on the other hand, the growing role of schools in teacher education and in-service teacher education. Schools will become so-called "training schools", which, among other things, means that they host the school practice of teacher trainees. In these schools, experienced teachers are employed as mentor teachers who received training in teacher education institutions. Although originally mentors are supposed to help teacher trainees, their support is often extended to beginning teachers as well (Major, 2014).

As teachers in Finland constantly review their teaching and educational work and, as a result, they reconsider possible changes from time to time, teachers and mentors supporting teacher candidates prepare students for this ideal inquiry orientation, a self-reflective, self-developing attitude during their studies (Jyrhämä \& Maaranen, 2012).

In Germany, the main goal is to have a strong practical orientation, to coordinate the training phases, to support teachers in the early stages of their career and to enhance the teachers' diagnostic and methodological competencies. In the first phase of the training, based on the theory of special sciences and pedagogy the teaching practice is introduced, and in the second phase, the theory-orientated reflection of the pedagogical practice is given priority. Thus, trainees gradually and systematically acquire the competencies required for independent teaching. The practice-oriented teacher education also affects public education, thus the primary goal in German schools is for students to develop independent learning strategies, work together in multicultural situations and 
projects, and be able to apply what they have learned optimally in practice. The third phase of the training is considered to be the in-service teacher education, in which, in the spirit of lifelong learning, teacher competencies are permanently developed. In Germany, the third phase of teacher education is the constant and continuous in-service education (Bikics, 2013; Hanisch \& Lichtenfels, 2009; Hillinger, Kossack, Lehmann, \& Ludwig, 2010).

\section{Striving for the Cooperation of Teacher Education Institutions, for the Creation of a Common Profession}

With regard to the institutional system of teacher education in Austria, according to the 2013 reform, universities and teacher training colleges implement teacher education programs in close cooperation with the aim of promoting the sustainability of teacher education, increasing the prestige and attractiveness of the teaching profession, supporting mobility and internationalization in the field of teacher education and balancing the status of teachers with the status of employees of other academic institutions (Simić et al., 2013). University colleges of teacher education, which were created by merging several previous teacher training institutions (Act of 2005 on Teacher Training and Education, which entered into force in 2006) play a significant role in teacher education.

In view of the countries which implemented the reform of their teacher education successfully, we can say that the solution does not only lie in the "production" of highly qualified teachers as it does not in itself bring about significant changes in educational achievements. Reform requires both better teachers and a better system.

The aim of the reform of the Hungarian teacher education system is to obtain the most effective results, keeping the positive elements of the existing system, with the least possible modification. The main goal of the change is to create an education system that provides students leaving the education institutions with a high level of professional knowledge and practice, so that they can effectively manage a group of students heterogeneous in knowledge and socialization at the beginning of their careers, thus creating equal opportunities for all students. The country is striving to organize into a unified system the initiatives established in recent years in the field of teacher education and in-service education, which have the same goals, i.e.:

(a) a competency-based teacher education approach;

(b) expanding the frameworks for practical training;

(c) linking theory and practice;

(d) the results of the development of a traineeship system based on initial education;

(e) the content development of the education institution and the practice schools and practice places, the coordination of their activities;

(f) developing the profession of the unit of teacher education institutions;

(g) coordinating the system of in-service education and initial education.

\section{Proposals to the Reform of the Teacher Education System}

In the following, we propose some modifications necessary to achieve the above goals, taking into account the international good practices mentioned above.

In Hungarian teacher education institutions, professional development is divided into disciplines and pedagogical and psychological methodologies. At present, theoretical preparation is sharply separated in time from practical teaching, due to which the coherence between theory and practice is not strong. As a result, the 
majority of beginning teachers have a hard time and encounter difficulties in performing their work effectively when they arrive at educational institutions. Although from 2012, the increase in the time interval of the previous six months of individual school practice to one year allows for the building of knowledge acquired in a more favourable practice than before, it is reasonable to increase the efficiency with a further increase in practical time.

In teacher training, the aim is to unify initial education, and in order to achieve this goal, numerous arguments can be put forward:

1. The principle that has been accepted in the practice of European teacher education for decades is the unit of the so-called "three i-s" (initial, induction, and in-service), the three phases of teacher education.

2. Hungarian teacher education professionals have also adopted this principle. The development of pedagogical competencies and the introduction of competency-based teacher education provide an appropriate theoretical and practical basis for the development of a unified system of the three trainings.

3. At the same time, the benefits of a unified harmonized system are yet to come at present.

4. If we are aware of the competencies to be achieved at the end of the induction phase, the preparedness required for independent teaching, it is also possible to provide support for the development of competencies in the most appropriate place. Competences or those elements of competencies that do not require full-time simultaneous school practice should be developed in the pre-traineeship phase of the initial training, and competencies that require practice but not related to specific school conditions should be developed in a coherent school practice while competencies related to specific school needs during the traineeship period, when the novice teacher is already confronted with the unique needs of his or her school.

5. The organization of the three training phases into a unified system is accepted by Hungarian teacher educators, and in principle the education policy does not oppose it, either.

6. A unified system would make it possible for the initial training to really provide the general foundations that a novice teacher absolutely needs in order to begin teaching. Preparation for most practice-oriented professions provides such a general foundation, and then trainee's (residency, etc.) training prepares the novice professional for special tasks.

7. Teacher training, and within this also specialist teacher training, intends to prepare trainees for the school level within the framework of initial education. Halfway through the undergraduate program, the student is given the choice of whether he or she wants to teach in a primary (Grades 1-8) or a secondary school (Grades 9-12).

8. The separation of these two levels is based on the expectations of the traditional school system. If we take into account the diversity of Hungarian schools today (4 grade, 6 grade, and 8 grade grammar school, vocational grammar school, and vocational secondary school), and all these in different parts of the country requiring very different training, the two kind, two-level teacher education does not cover the needs of these schools.

9. In the middle of the training, the student does not even know in advance which type of school he or she will get a job in.

10. All these arguments support that the initial training, the traineeship period should ensure trainees' adaptation to specific school conditions. The experience gained from a mentor should be supplemented with the necessary professional and pedagogical and psychological knowledge.

11. The Finnish teacher education system, which is considered as an example in the practice of teacher education, does not only differentiate in preparation for the senior section of the primary school (Grades 5-8) 
and secondary school (Grades 9-12), but it brings even the training and entitlement of class teachers closer together. The junior school teacher is entitled to teach the first six classes, and may even teach up to the ninth grade in the case of one or two A-level subjects.

12. We must not forget the flexibility of the unified teacher education, either. It is also easier for graduates to change schools, and it is also more appropriate to manage the workforce of teachers in a given school.

13. The classification of the teaching community into several levels according to the school level (primary or secondary) cannot be regarded as a desirable phenomenon either.

14. In the building/model, the "traineeship" period of the teacher-life career model is emphasized, which provides an opportunity for a beginning teacher with strong professional knowledge and expertise who did a very active teaching practice on a daily basis in the last year and a half to make a decision whether he/she wants to teach in a primary or secondary school, which can be greatly influenced by the education institution where the teacher begins his or her work.

As a consequence of the reform, the training must be extremely well-considered and practice-oriented, similar to the English, Dutch, and German practice. Its aim is for students to leave the training institutions with professional pedagogical knowledge and expertise. However, in order to achieve this, a strong disciplinary and methodological training content as well as a mentoring and evaluation system need to be attached to the model.

In the new model supported by mentoring, it seems ensured that the work of the teacher candidates in the practical field is guided and assisted by mentors on a daily basis. The student should receive immediate feedback on how to do their job effectively, in the process of which we consider immediate reflection and alignment, built in collaboration with the university and the practicing local mentor, to be one of the most effective factors.

The new system also requires a new type of relationship between the education institution and the traineeship places. The mentor plays a key role in the process of the student becoming a teacher. He/she can play this role if he or she can develop a unified approach between the education institution and the mentor and the school as a whole as is the practice in England and the Netherlands.

We need to talk about two types of schools that have a specific function in the process of trainees becoming a teacher. In the practice school, the basic pedagogical skills and competencies are developed in a laboratory environment. The network of schools operating as a traineeship place around the education institution enables the development of the student's own professional personality based on these abilities and competencies. The implementation of this task requires the coordinated training, in-service education and research and development work of the education institution, the practice school, and the external traineeship places.

Making practical training practice-oriented for students primarily means their doing regular teaching/work in the practice field. In parallel with acquiring pedagogical theoretical knowledge, from the beginning of the training to the end of the training, students lay the foundation of their knowledge by doing teaching practice on a regular and daily basis.

The aim of teacher education is to prepare students to be able to teach a heterogeneous group of students from diverse social backgrounds and with a wide range of abilities and knowledge, and to have the opportunity to try and apply their theoretical knowledge in practice.

In the following, we make some proposals for selecting a traineeship place that adequately develops students' knowledge, abilities, and skills.

Such a traineeship place should be selected for students that provides an opportunity:

(a) to get acquainted with high quality education and teaching; 
(b) to get acquainted with the school's self-development activities, to participate in them creatively;

(c) to fully participate in the pedagogical work;

(d) to develop professionally;

(e) to educate and teach a group of students who are heterogeneous in level of knowledge;

(f) to get support from a tutor and mentor teacher.

Organizing all these conditions in such a way that the university and traineeship place will become popular and important for students preparing for their teaching profession (see the English "teaching schools" and the Dutch "training school" practice). Such traineeship places are needed that give students the opportunity to gain excellent professional experience and deliver high-quality lessons, to gain an insight into the daily life of the school during their teaching practice and to establish relationships with children, the school, parents, and all partners cooperating with the school.

Teacher candidates should be supported in their work by a mentor/mentors and the simultaneous presence of a university lecturer/mentor and a teacher/mentor working in the practice school should ensure that their preparation is as efficient as possible. However, finding the right traineeship place can be difficult. It is important that the school serving as a traineeship place should not work with classes of selected students and groups, it should provide high-quality professional development for teacher candidates and it should be within reach of the education institution.

In order to create optimal conditions for initial education and in-service education, it is not enough to find and select schools that are close to the education institution and operate at a relatively good standard. In accordance with the international practice, where in some cases the whole teacher education is based on the traineeship place, a school endowed with the right to training (such as England and the Netherlands), traineeship places should play a significant role in the system of initial education and in-service education.

In Hungary, the movement of Professional Development Schools (PDSs) started in the 1990s. PDSs were actually created as a combination of practice schools, self-development schools, schools supporting the continuous professional development of teachers and schools embracing and presenting new results. It is therefore worthwhile to deal with PDSs in a little more detail, because they correspond best to both the patterns of becoming a teacher and aspirations of the educational policy for the professional development of teachers. A p PDS is a school that implements teaching and education at a high level, which is characterized by:

(a) the self-development orientation of the school, its operation as a learning organization, the school's openness to innovation and new pedagogical processes;

(b) participation in the practical training of the students of an education institution, a close, equal partnership with the education institution, covering the development of students, joint research and development, the involvement of university lecturers in the school workshop-like activities of the school;

(c) the PDS does not deal with selected children, but with children of different abilities and social backgrounds;

(d) the professional-development school, in cooperation with the education institution, participates in supporting the continuous professional development of teachers in certain regions by presenting and disseminating new methods, providing individual and group support for teachers and their communities in the region and organised in-service trainings.

Perhaps, it is not difficult to understand that the PDS outlined above provides more favourable conditions for the integrated, harmonious, professional development of students and practicing teachers than both in the 
practice school and the external traineeship places currently operating in a university setting.

Orgoványi-Gajdos and Zagyváné Szúcs (2019) summarized the main ideas of the PDSs as follows:

The concept was first formulated by the American Holmes Group. The PDS is an institution that provides optimal opportunities for both teachers and education administrators in terms of professional development. At the same time, it increases the professional relevance of higher education professionals by thinking through professional issues with students and seeking solutions together, sharing training tasks, collaboratively investigating problems in pedagogical practice, and jointly implementing professional supervision of students. (The Holmes Group, 1990)

Darling-Hammond (1994) pointed out that all agents involved in teacher education make equal contribution developing their professional knowledge and the practice of teacher education. It can help to develop new models of teacher education. (pp. 1-27)

The differences between a traditional practice school and a PDS are highlighted by the following two definitions:

Development-research and in-service training, involving teachers, research teachers, students and education administrators alike, provide a broad-based partnership that is not comparable to the activity of a traditional practice school, focusing almost exclusively on teacher education. The latter generally lacks the need for innovation, renewal of practice, and collaborative research. (Shen, 1993, pp. 80-81)

A PDS differs from an existing practice school in the fact that it relies on the collaboration of university lecturers, researchers, and lead teachers as equal partners.

A creative workshop for developing and disseminating of state-of-the-art processes based on jointly achieved new scientific results and practical experience, in which research, teacher education, and in-service education take place in a mutually beneficial manner. This model also assumes a wide network of well-trained mentors who regularly join the workshop to help students and beginning teachers. The continuing professional development of an experienced teacher is ensured by innovation, research, and development, and it is also worth involving teacher candidates in this. This is how the school can become a creative workshop capable of constant renewal.

There are four basic conditions required to create a new type of partnership between the school and the training institution:

(a) preparing teacher education students for traineeships;

(b) professional development;

(c) research;

(d) supporting teacher education students' learning.

All of these conditions define new types of roles for participants. In this type of partnership, it is often the case that a researcher becomes a teacher or a teacher becomes a researcher, and teachers become students. In order for the initial conditions listed to be met, new types of tasks must be performed by principals, teachers, and of course, university lecturers. Cooperation is the key word, which entails shaping and developing relationships with each other consciously (PDS Standards).

The question arises as to what degree of cooperation is needed. It was possible to establish true collegial relationships between the participants in those PDSs where a wide variety of innovative activities were carried out. At the same time, the performance of the narrower tasks did not require democratic forms of common thinking and decision-making, and a moderately autocratic management system was able to show results as well. 
Adequate funding is needed to build the system, including support for the traineeship mentor and providing the traineeship place with the equipment needed for the training.

\section{Proposals to Transform the Student Mentoring System}

Relying on the practice of the countries examined above, when formulating our proposals related to the Hungarian mentoring system, we strive to create a strong system appropriate for judging and assisting student work. When formulating the requirements of the mentoring system, we take the following into account (Falus \& Nagy, 2018):

(a) Building a strong relationship, professional cooperation between the university and the base/practice/PDS;

(b) Perceiving learning and teaching as a coherent whole, raising awareness of the fact that its lack jeopardizes and reduces the effectiveness of training;

(c) Implementing effective communication among teachers, university and school mentors, and students in order to establish a closer link between the theoretical and practical aspects of training;

(d) Close cooperation and equality, creating communication on an equal footing between the student and the tutor;

(e) Formulating criteria for excellence (high professional/subject knowledge, underpinning theory with practice, methodological diversity, continuous evaluation, and success orientation);

(f) Strong fieldwork supervision (weekly follow-up and quarterly assessment);

(g) Strong student commitment to the teacher education institution.

It became necessary to transform the Hungarian student mentoring system, to provide mentoring support to students as follows:

1. Students' work is supported by a (ideally two) mentor(s), a university professional (a subject teacher or one who assists pedagogical work), a teacher (hereinafter "tutor"), and a mentor (hereinafter "lead teacher") working at the traineeship place. Their task is to prepare students for field work and for their future teaching profession.

2. The mentoring system includes regular and mandatory consultation. The tutor and the lead teacher who guide the traineeship do not only formulate advice and recommendations, but they also discuss the experiences of practice teaching with the student as equal partners, the aim of which is to develop students' self-reflection and self-development skills. In Finland, the Peer Group Mentoring was set up at the initiative of the University of Jyvaskula. This system, built on social constructivist pedagogy, states that students are able to construct their own knowledge if people with similar experiences discuss these experiences and their knowledge in the academic literature in groups. The practice in recent years proves that this group mentoring complements the development work assisted by a qualified mentor effectively and efficiently. At the same time, the school develops the novice teacher's skills of undertaking self-development activities.

3. Mentors keep a "personal development diary" of the student.

4. Developing an assessment system for diagnostic, formative and summative performance assessment.

5. The relationship among tutor, lead teacher and student is characterized by strong mentoring support and personal, day-to-day counselling.

6. A university tutor has more than 5-10 students.

The goal of mentoring is to facilitate change that recognizes and identifies difficulties through mutual learning and brings about the desired intervention. It is important that the need for change should be characteristic 
of all actors (tutor-lead teacher-student), meaning commitment, establishing partnerships, learning while performing work and developing students' strengths. The tutor/lead teacher should have the need to share his/her knowledge and experience with the student, intends to spend time building a good relationship with the mentee based on trust and honesty, and builds on the mentee's personal strengths, needs, and knowledge.

The process is assisted by qualified tutors and lead teachers. As a result of preparation, they exhibit the following abilities (Sallai, 2014):

(a) effective professional cooperation and communication;

(b) providing individual support for the student's professional socialization;

(c) recognising, developing, and assessing professional competencies;

(d) guiding students' experience and learning process in various forms (in-class and out-of-class);

(e) giving constructive feedback, developing assessment;

(f) organising and presenting state-of-the-art and good practice.

We formulate guidelines to help the beginning trainee, which we also consider valid to help the student's traineeship period (Sallai, 2014):

1. Assisting trainees: There is a need for institutional support for the induction phase, for which mentors will receive assistance at the national level.

2. Assisting university practice: The student's practical work is systematically assisted by a tutor and a lead teacher.

3. Assisting trainees: We consider it necessary to make the at least 120-180 hours of seminar teacher mentor teacher training a commonly used practice and to strengthen that only a qualified mentor can work with a trainee or a student doing his or her traineeship. In mentor training, special attention should be paid to the development of the skills necessary for state-of-the-art, facilitative and supportive mentoring. The development of helping skills, which are also necessary for the development of reflectivity, requires guided practice within the framework of training, for which an appropriate number of lessons must be provided. At least $50 \%$ of the mentoring program should be devoted to practising helping skills. At the same time, much more emphasis should be placed on training mentors in the basic module (diagnostic assessment, preparing development plan, and assisting portfolio preparation, etc.).

4. Assisting university practice: In addition to the above requirements, we consider it necessary for university tutors to complete 10-30 hours of tutor training.

5. Assisting trainees: The qualification requirements for mentor training need to be reviewed due to renewable content elements, e.g., preparation for the qualifying exam.

6. University practice: Students' work can be assisted by both a research and a research-teaching university specialist.

7. Assisting trainees: We consider it necessary to develop and operate other modules in addition to the basic mentoring module in order to support the induction phase.

8. Assisting trainees: We consider it necessary to create regional mentor-trainee workshops where both mentors and trainees can meet in person.

9. Assisting university practice: It appears as a requirement that tutors and lead teachers cooperate continuously, discuss and assess students' performance on a weekly and quarterly basis.

10. Assisting trainees: We strengthen the proposal that mentors should have a separate website where they can also exchange experiences. 
11. Assisting trainees: We propose that the professional, administrative and ethical issues of non-specialist mentoring be addressed separately.

12. Assisting trainees: We propose that the possibility of time allowance and extra pay for mentors based on mentoring opinions be considered.

13. Assisting university practice: The university tutor should receive an extra pay for his or her work.

14. Assisting trainees: A novice mentor should also have a mentor or a supervisor.

15. Assisting university practice: The student's work assisted by the lead teacher should be guided by the tutor.

16. Assisting trainees and organizing university practice: Mentors should be in close contact with each other. They should interpret the expectations of teacher candidates together.

\section{Proposals for Harmonizing the Theory and Practice of Education and Creating Its Organic Unity}

Teacher education in Germany, the Netherlands and England is a good example of how to create the unity of theory and practice, and to ensure that they build on each other. In Hungary, teacher education does not prepare students adequately to make a smooth transition from school to the world of work, the curriculum theory and practice are not linked, do not form an organic unit and traditional lectures and tests are still common and widely used at universities. However, theoretical preparation and strongly guided and controlled practical training can provide high level preparation for prospective teachers, which is one of the cornerstones of making teacher education effective.

In recent decades, significant efforts have been made to increase the practice orientation of teacher education. Actual school visits in the induction phases of the training, a specific number of analyses of teacher and student activity, lesson research, and the active use of video recordings to illustrate problems and help students solve them, the use of micro-teaching and other laboratory methods were intended to create the organic interconnection between theory and practice. Efforts have also been made and are being made to systematically incorporate the various forms of practice that presuppose student activity and independence into the course of the training.

In recent years, efforts have also been made to increase the number of seminars and credits within the pedagogical training. However, when we introduced undivided training, we witnessed two serious failures in this regard. On the one hand, the pedagogical predominance experienced at the time of the introduction of the Bologna system was dramatically changed, and pedagogical training was pushed into the background due to the over-representation of the proportion of specific subjects. The other failure is due to the fact that the number of seminars predominated within the pedagogical training, the theory could not fulfil the function of interpreting and supporting the practice. This distortion was further increased by the temporal placement of the practice, its temporal distance from theoretical training. In the induction phases of the training, the theory deprived of the possibility of linking it with practice is followed by a one-year practice that appeared in the last phase of the training. Thus, there is no way to ensure the right combination between theory and practice, either. It must be seen that in the professional development of a teacher, a mutual interdependence between theory and practice needs to be established. It is not just that the student should apply the acquired theoretical knowledge in practice, and it is not just that he or she should interpret and organize his or her practical experiences with the help of theory. 
Developing teachers' set of views, decision-making abilities, practical activities, skills and repertoire of skills presupposes the process of students' knowledge construction. In this process, the student's existing set of views at the time of entering training must be revealed, and they must be confronted with practical tasks in which it becomes clear whether he or she can apply his or her existing set of views and assessment system, or cannot. Within the framework of these practical activities, the student's set of views are formed and changed with external support, and the practical skills necessary for implementing his or her conception and approach are also changed and honed. This process is only effective if the theoretical and practical components follow each other at almost the same time, the student's set of views is directly formed as a result of practice, and this is supported by the theoretical knowledge required and made available by practice. The next practical phase provides the possibility to apply the changed set of views. The processes that take place in this organic unit can ensure the teacher's effective professional development and his/her independent but supported knowledge construction and skills.

Thus, the condition for this process is that the mutual interdependence between theory that can be applied in practice and practice that supports theory be established. Effectiveness includes creating a mutually supportive effect system. A university providing outdated theory that cannot be used in practice and outdated teaching methods is as much an obstacle to effective teacher education as the practice in conventional schools that is insensitive to new procedures. Thus, a cooperative university and school, a university lecturer open to practice and a school that develops itself using the same approach as the education institution are essential for effective teacher education. It is crucial to create this network of schools around the university and the teacher education professionalism of teachers who are interested in practice and immerse themselves in it. A culture of this must be created and mentors need to be prepared for this work (through trainings).

The aim is to eliminate the above shortcoming so that teacher candidates can face educational situations that will later help them with their future teaching career. This requires a curriculum, theoretical, and practical preparation in which a close link is established between the real world of schools and teacher education. The basic concept is that even non-field, in-house training should be strongly practice-oriented; materials from real school practice (e.g., videos, studies, student portfolios, etc.) should come to the fore in teacher education. By using them, teacher candidates can practice interpreting and analysing pedagogical situations. This type of teacher education facilitates the development of pedagogical skills, understanding the adaptation constraints associated with the profession, and the demand for continuous professional development (Darling-Hammond \& Sykes, 1999; Nagy, 2018).

We propose that analysis of teaching and learning as a new pedagogical practice appear as a new subject in the teacher education process. This should be information and communications technology (ICT)-supported learning that draws attention to numerous cases, focusing on areas, such as the teacher candidate's classroom behaviour, student reaction, and tasks related to curriculum development.

\section{Proposals to Expand the Professional Knowledge of Teachers in Education Institutions, to Create a Teacher Education Profession, to Develop the Competencies of Teacher Educators}

The preparedness of graduating students is significantly influenced by the quality of the education and teaching in the institution. This can be partly related to scientific knowledge and recent research results. According to Csapó (2016), "the knowledge that can be transferred to teacher candidates is also well characterized by the scientific quality and research capacity of the training places.” 
In addition, we also consider it as a determining factor what teaching experience the teachers in teacher education institutions in a public educational institution gained before or in parallel with their research work. We believe that teachers who have this kind of experience and practical knowledge are more likely to be able to prepare students for field work. In this field, it is desirable to continuously expand teachers' pedagogical knowledge and methodological repertoire. It is important to point out that non-recent approaches are less effective, methods used successfully in a particular context may be less successful in other situations, and it is important to combine various methods instead of using individual ones by themselves.

We propose separating the status of researcher and researcher-teacher and recognizing the difference between them with an allowance in favour of the latter.

1. The researcher devotes his or her entire activity to the research work.

2. In addition to doing high-level research, the researcher-teacher also plays a role in training students in possession of his or her high-level pedagogical knowledge.

We propose developing a system that ensures the continuous methodological development of researcher-teachers and allows students to acquire the latest and practically applicable scientific knowledge. Of the countries studied, Austria and England are good examples of this.

When describing the competencies of teacher educators, we made an attempt to summarize the expectations of teachers as teacher educators based on international experience and European Union (EU) guidelines. They are discussed in detail in the volume "Competences of teacher educators” (Falus \& Estefánné, 2015). The authors of the volume embrace the notion that high-quality teacher education and in-service training are realised only through the activities of a unified community of teacher educators. We consider teacher educators as professionals involved in the education and professional development of teachers, including teachers of specific subjects, pedagogy, psychology, subject pedagogy, in-service trainers, lead teachers, and mentors of practice schools. Teacher educators have a dual identity.

They have the expertise corresponding to their original specific subject, discipline but in addition, they also have the specific knowledge and skills characteristic of teacher educators. The book lists the competencies that make up the specific teacher education profession. It is important to recognise that a teacher who teaches at school, a professor of history, or a teacher of pedagogy and methodology have an equal responsibility to support students in becoming teachers. It should also be understood that all of these individuals can be considered unqualified until they possess the profession of specific teacher education.

Teacher educators must have the following competencies (Falus \& Estefánné, 2015):

(a) Demonstrating high-level teaching abilities and skills, i.e., possessing pedagogical competencies (students will teach to a significant extent in the way they are taught, thus, we expect all teacher educators to become role models for students through how they perform their duties).

(b) Supports the process of candidates' professional development, facilitates their career socialization (possessing the competence means that the teacher educator is aware of the goals the candidate needs to achieve, their state of preparedness and he or she is able to support them in designing and implementing their individual development plan).

(c) Cooperates with other persons and organizations participating in teacher education (it is enough to point out the importance of continuous cooperation between various teachers and mentors here).

(d) Continuously analyses and reflects on his or her own activities, is committed to his or her continuous professional development. 
(e) Carries out research related to teaching, learning or teacher education, bases his or her activities on research results.

(f) Takes responsibility for ensuring and developing the quality of teacher education and public education.

(g) Contributes to developing the teacher education activities within the institution.

In his/her approach and practice, he/she keeps within the international trends in teacher education and public education. It is clear from the competencies required of teacher educators that the preparedness and responsibility of a professional who can contribute to raising the standard of teacher education, differs from that of a professional who teaches at school or teaches and primarily carries out research at a university.

Part of quality assurance and marketability is to place special emphasis on student feedback on faculty performance. We recommend that anyone who is a good researcher but has weak spots in teaching should not take on this task, especially with regard to core subjects that require an affinity with teaching. In this regard, we propose:

(a) giving strong consideration to student opinion;

(b) rethinking the theme or possibly deleting the subject in the case of too negative student opinion of particular subjects;

(c) greater interdisciplinary coordination, a good example of which is Austria.

\section{Summary}

Nowadays, there is a strong interest in the higher education sector. It is not only because there is a clear increase in the demand for graduates, but also because social actors are setting increasingly high expectations for the effectiveness in higher education.

In our paper, we summarized the circumstances that created the need to reform the Hungarian teacher education, which are the good European examples that can have an impact on launching transformation. In the light of the latter, we formulated proposals to make improvement, which may help or have helped to start the reform of Hungarian teacher education. We primarily focused on making proposals for implementing a more practice-oriented training that gives more priority to methodology. The reform has entered the preparatory phase and is expected to be introduced from 2021.

\section{References}

Bikics, G. (2013). Tanártovábbképzés Németországban (In-service teacher training in Germany). In I. Falus (Ed.), Pedagógus-továbbképzés (In-service teacher training) (pp. 251-312). Nemzetközi áttekintés (International overview). Líceum Kiadó. Eger.

Bikics, G. (2018). Németország (Germany). In I. Falus and K. E. Nagy (Eds.), A hazai pedagógusképzési rendszer helyzete nemzetközi összehasonlításban. Kézirat (The situation of the Hungarian teacher education system in international comparison: A manuscript). Századvég Alapítvány (The Századvég School of Politics Foundation).

Csapó, B. (2016). A tanárképzés és az oktatás fejlesztésének tudományos háttere (The scientific background for the development of teacher training and education). Iskolakultúra (School Culture), 26, 2.

Darling-Hammond, L. (1994). Professional development schools: Schools to develop profession (p. 68). New York: Teacher College Press.

Darling-Hammond, L. (2006). Constructing 21st-century teacher education. Journal of Teacher Education, 57(10), 1-15. DOI: $10.1177 / 0022487105285962$

Darling-Hammond, L., \& Sykes, G. (1999). Teaching as the learning profession: Handbook of policy and practice. Wiley.

Department for Education. (2017, November). TALIS 2013 Working Conditions, Teacher Job Satisfaction and Retention Statistical Working Paper. Sam Sims, Education. 
Department for Education. (2018). Get into teaching. Retrieved May 16, 2019, from https://getintoteaching.education.gov.uk/explore-my-options/teacher-training-routes

Dutch Inspectorate of Education. (2015). Background information and working method of the inspectorate. Department of International Affairs Dutch Inspectorate of Education. Retrieved February 20, 2018, from http://www.onderwijsinspectie.nl/english.

European Commission. (2017). Education and Training monitor 2017, Netherlands, Directorate-General for Education and Culture. Luxembourg: Publications Office of the European Union. Retrieved February 20, 2018, from https://ec.europa.eu/education/sites/education/files/monitor2017-nl_en.pdf

Falus, I., \& Estefénné-Varga, M. (Eds.). (2015). A pedagógusképzők kompetenciái (Competences of teacher educators). Eger: EKF Líceum Kiadó.

Falus, I., \& Nagy, K. E. (Eds.). (2018). A hazai pedagógusképzési rendszer helyzete nemzetközi összehasonlításban: Kézirat a politikai döntéshozók számára (The situation of the Hungarian teacher education system in international comparison: A manuscript for policy makers). Budapest.

Gov.UK. (2010). The importance of teaching: The schools White Paper 2010. Retrieved February 20, 2018, from https://www.gov.uk/government/publications/the-importance-of-teaching-the-schools-white-paper-2010

Graduate Prospects Ltd. (GB). (2018). How to become a teacher. Retrieved May 6, 2020, from https://www.prospects.ac.uk/jobs-and-work-experience/job-sectors/teacher-training-and-education/how-to-become-a-teacher

György, L. (2015). Szingapúrban oktatnak (They teach in Singapore). Retrieved April 1, 2018, from http://mozgasterblog.hu/blog/szingapurban_oktatnak

Halász, G., Santiago, P., Ekholm, M., Matthews, P., \& Mackenzie, P. (2004). Anwerbung, berufliche Entwicklung und Verbleib von qualifizierten Lehrerinnen und Lehrern Länderbericht: Deutschland Organisation für wirtschaftliche Zusammenarbeit und Entwicklung Direktion Bildungswesen Abteilung für Bildungs- und Ausbildungspolitik (Recruitment, professional development and whereabouts of qualified teachers Country report: Germany Organization for Economic Cooperation and Development Directorate for Education Department for Education and Training Policy). In I. Falus and E. K. Nagy (Eds.), A hazai pedagógusképzési rendszer helyzete nemzetközi összehasonlításban (The situation of the Hungarian teacher education system in international comparison: A manuscript). Századvég Alapítvány (The Századvég School of Politics Foundation).

Hanisch, R., \& Lichtenfels, M. (2009). Trends und Tendenzen in der Lehrkräftefortbildung. Päd Forum, 1, 17-20. Retrieved January 9, 2013, from http://www.pedocs.de

Hillinger, B., Kossack, P., Lehmann, U., \& Ludwig, J. (2010). Die bedarfsorientierte Weiterentwicklung von Studieneingangsphasen. Ein Projektbericht aus der Universität Potsdam (The needs-based further development of study entry phases. A project report from the University of Potsdam). Das Hochschulwesen (The higher education system), 4+5, 134-139.

Jyrhämä, R., \& Maaranen, K. (2012). Research orientation in a teacher’s work. In H. Niemi, A. Toom and A. És Kallioniemi (Eds.), Miracle of education: The principles and practices of teaching and learning in Finnish schools (pp. 97-117). Sense Publishers, Rotterdam.

Nagy, E. K. (2017). A digitális eszközök helye a Komplex Instrukciós Program szerint szervezett tanórákon (The place of digital devices in lessons organized according to the Complex Instruction Program). Iskolakultúra (School Culture), 27(1-12), 86-97.

Király, Z. S. (2018). Anglia. In I. Falus and E. K. Nagy (Eds.), A hazai pedagógusképzési rendszer helyzete nemzetközi összehasonlításban. Kézirat (The situation of the Hungarian teacher education system in international comparison: A manuscript). Századvég Alapítvány (The Századvég School of Politics Foundation).

Major, É. (2014). A kezdő tanárok támogatása, szakmai profil és tanári kompetenciák Hollandiában (Support for beginning teachers, professional profile and teacher competencies in the Netherlands). In F. Arató (Ed.), Horizontok: A pedagógusképzés reformjának folytatása (p. 231). Autonómia és felelösség tanulmánykötetek, 219-228. Retrieved September 10, 2015, from http://kompetenspedagogus.hu/sites/default/files/11-Arato-Ferenc-szerk-Horizontok-pte-btk-ni-2014_0.pdf

Major, É. (2018). Hollandia. In I. Falus and E. K. Nagy (Eds.), A hazai pedagógusképzési rendszer helyzete nemzetközi összehasonlításban: Kézirat (The situation of the Hungarian teacher education system in international comparison: A manuscript). Századvég Alapítvány (The Századvég School of Politics Foundation).

McKinsey \& Company. (2007). How the world's best-performing schools come out on top. Retrieved March 8, 2018, from https://www.mckinsey.com/industries/social-sector/our-insights/how-the-worlds-best-performing-school-systems-come -out-on-top 
OECD. (2017). Education at a glance OECD indicators 2017. Retrieved May 6, 2020, from https://www.keepeek.com//Digital-Asset-Management/oecd/education/education-at-a-glance-2017_eag-2017-en\#page362

Orgoványi-Gajdos, J., \& Zagyváné-Szücs, I. (2019). The complementary school-university partnership through the lens of a learning community. Journal of Teacher Education and Educators, 9(1), 107-124.

Pesti, C. S. (2018). Ausztria. In I. Falus and E. K. Nagy (Eds.), A hazai pedagógusképzési rendszer helyzete nemzetközi összehasonlításban: Kézirat (The situation of the Hungarian teacher education system in international comparison: A manuscript). Századvég Alapítvány (The Századvég School of Politics Foundation).

Robinson, W. (2006). Teacher training in England and Wales: Past, present and future. Educational Research and Perspectives, 33(2), 19-36.

Retrieved March 29, 2018, from http://www.bildungsserver.de/Lehrerbildung-816.html

Retrieved February 20, 2018, from http://www.kmk.org/fileadmin/Dateien/veroeffentlichungen_beschluesse/2013/2013_12_05-estaltung-von-Sondermassnahm en-Lehrkraefte.pdf )

Retrieved March 29, 2018, from https://www.sool.fi/sool/

Sallai, É. (2014). A pályakezdő tanárok támogatásának és minősítésének hazai előzményei (Domestic antecedents of support and qualification of beginning teachers). In I. Falus (Ed.), A pedagógus gyakornoki rendszer. Nemzetközi áttekintés. Hazai elözmények (The teacher traineeship system. International overview: Domestic history) (pp. 135-176). Oktatási Hivatal, Budapest.

Simić, N., Bachmann, G., \& Stančić, M. (2013). Comparison of teacher education reforms in Serbia and Austria. In D. Miomir, H. Emina and N. Balázs (Eds.), Contemporary issues of education quality (pp. 393-408). Belgrade: Faculty of Philosophy, University of Belgrade, Serbia-Institute for Pedagogy and Andragogy, University of Belgrade, Serbia-Faculty of Adult Education and HRD, University of Pécs, Hungary.

Szabó, P. T., \& Kärkkäinen, K. (2018). Finnország (Finland). In I. Falus and E. K. Nagy (Eds.), A hazai pedagógusképzési rendszer helyzete nemzetközi összehasonlításban. Kézirat (The teacher traineeship system. International overview. Domestic history: A manuscript). Századvég Alapítvány (The Századvég School of Politics Foundation).

Teaching 2020, A strong profession. (2011). Ministry of Education and Culture and Science. Retrieved October 25, 2017, from https://www.educ.cam.ac.uk/centres/lfl/about/events/pastlflsupperseminars/pdfs/Teaching_2020_The_Netherlands_Ministry. pdf

The Holmes Group. (1990). Tomorrow's schools: East Lansing, Principals for the design of professional development school. East Lansing, MI: Holmes Group.

Universities and Colleges Admissions Service (UCAS). (2018). Teacher training entrance requirements in England. Retrieved from https://www.ucas.com/teacher-training-entry-requirements-england

Varga, J. (2012). Katasztrófa lenne egy Medgyessy 2.0-féle béremelés (Medgyessy’s 2.0 salary increase would be a disaster). Új Katedra (New Teacher's Desk), XXIV/9. 7.

15/2006. (IV. 3.) OM rendelet az alap- és mesterképzési szakok képzési és kimeneti követelményeiröl. (OM Regulation of the Ministry of Education (OM) on the training and output requirements of for bachelor and master programs). Retrieved March 8, 2018, from http://cdn.felvi.hu/bin/content/dload/jogszabalyok/15_2006_alap_mester_kkk_20080201.pdf 